度 $0.38 \%$ であった。 また, 三宅島内のラドン散逸率は検出下限值以 下，トロン散逸率は $38 \mathrm{mBq} / \mathrm{m} 2 \cdot \mathrm{s}$ であり，いずれも 1 都 9 県の平均 值 (ラドン散逸率： $7.6 \mathrm{mBq} / \mathrm{m} 2 \cdot \mathrm{s}$, トロン散逸率： $690 \mathrm{mBq} / \mathrm{m} 2 \cdot \mathrm{s}$ ) と比較して非常に低い值であった。散逸率も空間ガンマ線線量率や 天然放射性核種濃度と同様に地質に依存する報告があり, 本結果も その傾向を示していた。

\section{5 放射線防護シートの劣化及び保存方法に関する研究} 東京都立保健科学大学・放射線学科 三浦更紗，日高章吾 首都大学東京 大谷浩樹

日本大学大学院・理工学研究科 奥 洋平

【目的】放射線を扱う上で, 被曝量の減少を可能にする放射線防護衣 は欠かす事ができない。しかし，施設によって防護衣の保存方法が 異なり，適切な保存をしないために防護衣が破損するという現状が ある. 更に, 破損した防護衣を使用した病院職員の被曝も懸念され る.このような状況から, 本研究ではメーカー推奨の保存方法(ハン ガーに吊るす)と他の保存方法での防護衣の劣化の程度を調べる事を 目的とした。 また，推奨された点検・検查方法により破損状態を検 討した.

【方法】防護シート(厚さ $0.25 \mathrm{~mm}, 0.35 \mathrm{~mm}, 0.5 \mathrm{~mm})$ をそれぞれ切り分 けた．同じ部位で折りたたむ方法(保存する際も折りたたんで保 存), 手で搡む方法 (無造作に放置する保存方法の代用), 同じ部位を 棒にかける方法を繰り返した，それぞれメーカー推奖の目視・触覚 による点検と透視検査を行った上で透過線量を測定した。測定方法 は面積線量計の上に防護シートを乗せ, 透視した。測定条件は照射 野 $10 \times 10 \mathrm{~cm}^{2}, S S D 100 \mathrm{~cm}$, 透視時間 1 分, 管電圧: $50,80,115 \mathrm{kV}$ とした.

【結果・考察】それぞれ劣化させたシートの透過線量は, 劣化させる 前のシートの透過線量と比較すると, 差異がほとんど表れなかっ た.これは, 面積線量計で平均して測定しているので顕著な結果が 出なかったためと考えられる。目視・触覚に関しては, 折りたたん だシートでは早い時期から異常を確認する事ができた。透視に関し ても，折りたたんだシートでは早い段階から折りたたんだ跡が現れ た。これは，同じ部位を折りたたむ事により，他の方法より損傷が 早かったためと考えられる。

\section{6 マイクロ波治療器用シールドカーテンの性能評価}

千葉大学大学院・目然科学研究科 大木 登

千葉大学・伊藤研究室 中山万奈美

千葉大学フロンティアメディカル工学研究開発センター 伊藤公一

【目的】国内普及10万台のマイクロ波治療器が55例中 2 例MRIに, 3 例がX線CTに何かしらの障害を与えているという報告が日本放射線 技術学会誌第68巻第 5 号に掲載された。今回, 医療機器への誤作動 を防ぐための簡易シールドの必要性を感じ, マイクロ波治療器用 シールドカーテンを製作し，その性能評価をしたので報告する.

【万法】シールドカーテンは心材としてアルミガラスシートを使用 し, 1 枚のシート $215 \times 20 \mathrm{~cm}$, 中央に $160 \times 14 \mathrm{~cm}$ の穴をあけ金網を挟む ように両面テープで接着させている. 合計 35 枚のアルミシートと金 網のセットをその而面に導電紙を張り合わせ, 折りたたんで収納可 能なアコーディオン型とした。カーテンでかこんだ範囲は $180 \mathrm{~cm} \times 300 \mathrm{~cm}$, シールドカーテンより $50 \mathrm{~cm}$ 離れた点を測定点とし た. 中央に脳等価ファントムを設置, 照射出力50Wでシールドカー テンの垂直面の二次元電界強度分布を測定し, シールド無しの自由 空間と比較した．金網の使用は換気と患者様の観察である。

【結果】その結果は最大で-14dB, 同じ形状で設置場所を理学療法室 にした時の最大值-17dBのシールド効果に比較しても低い值であっ た.

【考察】当初考えていた目標値より低い結果になったのは, 照射アン

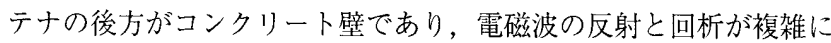
絡み合った結果と考えられた。

【結語】設置場所や設置環境によりシールド効果に大きな差が出る可 能性もあり, 事前の設置場所の調査が必要である。また，オプショ ンで電波吸収体を使用するなど個々に対応してシールド効果を上げ る必要がある。なお, 本研究は千葉県福祉・医療機器研究会の会員 企業との共同研究であり，今後よりよい簡易シールドの製作をして いく予定である.

107 陽電子消滅ガンマ線に対するX線防護用鉛ガラスの遮へい効果 国立がんセンター中央病院・放射線診断部 山口裕久，大崎洋充 村石泰伸, 塚田 勝

【目的】鉛ガラスに対する陽電子消滅ガンマ線に対する透過率を求め る.

【使用機器】電離箱式サーベイメータ アロカ(株)ICS-321 鉛ガラス 日本電気硝子 (株) LX $-57 \mathrm{~B}(20 \mathrm{~cm} \times 20 \mathrm{~cm})$ 厚さ $7 \mathrm{~mm}, 9 \mathrm{~mm}, 11 \mathrm{~mm}$, $14 \mathrm{~mm}$, 線源 68-GePhantom Source, Sanders Medical Products社 PET$20 \mathrm{c} 19 / 3.2,120 \mathrm{MBq}(2004 / 12 / 8)$ 線源移動用専用容器 ECAT ACCEL用 シーメンス(株)鉛ブロック， $200 \mathrm{~mm} \times 100 \mathrm{~mm} \times 50 \mathrm{~mm}$

【方法】電離箱式サーベイメー夕を用い $1 \mathrm{~cm}$ 線量当量率を測定し透過 率を計算した１．線源の状態 線源移動用専用容器の上に鉛ブロッ クを置き，線源表面を $10 \mathrm{~cm} \times 10 \mathrm{~cm}$ とした． 2. 幾何学的配置 (1) 測定 器の実効中心一線源表面間距離を $30 \mathrm{~cm}$ 一定, (2)鉛ガラスー測定器 表面間距離を $5 \mathrm{~cm}$ 一定.

【結果】 ${ }^{68} \mathrm{Ga}$ (照射野10×10)での鉛ガラスの透過率を求めた結果，鉛ガ ラス $50 \mathrm{~mm}$ で $10 \%$ となった。

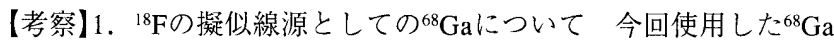
は，陽電子以外に $1 \mathrm{MeV}$ 超える光子も放出している，PET検査で 最も多く用いられている ${ }^{18} \mathrm{~F}$ と ${ }^{68} \mathrm{Ga}$ を比較すると, 放射線施設のしゃ へい計算実務マニュアルでは，鉛厚 $10 \mathrm{~mm}$ に対する各線源の実効線

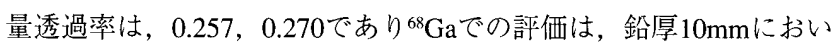
ては約 $5 \%$ 安全側となる。2. エ、ネルギーによる鉛当量の変化測定 に使用した，鉛ガラスのメーカー資料(JIS Z4501，X線防護用品類の 鉛当量試験法)に基づいた鉛当量では，総厚 $45 \mathrm{~mm}$ が，鉛当量 $10 \mathrm{~mm}$ と算出できる．実験結果から，鉛ガラス厚 $45 \mathrm{~mm}$ で，鉛当量約 $15 \mathrm{~mm}$ となり，その差は $5 \mathrm{~mm}$ となった.

謝辞 本研究を進めるに当りご指導をいただきました国立保健医療 科学院 山口一郎先生に樑謝いたします。

\section{X線装置始業点検の意義}

昭和大学病院 ·放射線部 石田秀樹，武 俊夫，岡部圭吾, 斉藤 肇 秋山真之, 中澤靖夫

【目的】近年, 医療社会を取り巻く環境が大きく変化しており，とり わ忛，医療技術の質の保証について診療放射線技師としてできる事 はなにかが問われている，今回，始業点検の成果として検査または 治療前に故障を見い出し，検査または治療に支障を少なくできた事 例について報告し，始業点検の意義について報告する．

【対象および方法】1)対象は，一般撮影用X線装置，X線テレビ装置, X線血管撮影装置, X線CT装置, MR装置, 放射線治療装置, 核医学 装置, CR装置, レーザーイメージャー, 自動現像機の合計109台と した。 2) 今回の調査期間は 1995 年 4 月から 2005 年 4 月までの 10 年間 とした．3)対象別に実際の使用状況に促したチェックシート(仕業点 検表・故障修理記録)を使用した．4）毎朝，毎夕，担当部門が検查ま たは治療前にチェックシート (仕業点検)の項目に従い点検を実施し た. 5)故障が発生したら，そのたびに対象別装置故障記録用紙へ記 録した，6）実施状況や成果について定期的に各部門で検討し，まと めてから放射線機器管理委員会に提出し, 詳細に分析して, 統計を 集計した。 